\title{
Lost Medical Device
}

National Cancer Institute

\section{Source}

National Cancer Institute. Lost Medical Device. NCI Thesaurus. Code C112329.

A finding referring to a medical device that is no longer held or possessed; incapable of being recovered or regained. 